\title{
Effect of Integrated Nutrient Management in Red Cabbage Grown under Shade House Condition
}

\author{
Shruti Koppad $^{1 *}$, S. M. Mantur ${ }^{1}$, M. S. Biradar ${ }^{2}$ and Shripad Kulkarni ${ }^{2}$ \\ Department of Horticulture, College of agriculture, Dharwad, University of agricultural \\ sciences, Dharwad - 580 005, Karnataka, India \\ *Corresponding author
}

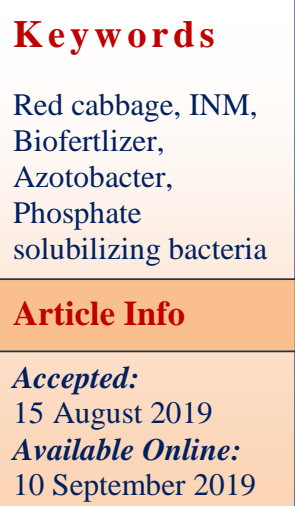

A B S T R A C T
A field experiment was conducted during rabi, 2015-16 at Hi-Tech Horticulture Unit, University of Agricultural Sciences, Dharwad to investigate the "Studies on integrated nutrient management in red cabbage grown under shade house condition". The treatments consists of three levels of recommended dose of fertilizer that is $100 \%(100: 150: 125 \mathrm{~kg}$ NPK/ha) and $75 \%(75: 112: 75 \mathrm{~kg} \mathrm{NPK} / \mathrm{ha})$ and 50 \% RDF (50:75:62.5 kg $\mathrm{NPK} / \mathrm{ha})$, three levels of recommended dose of nitrogen $(100 \%, 50 \%$ and $50 \% \mathrm{RDN}$ ) provided through FYM and vermicompost and bio-fertilizers (Azotobactor and PSB). Among the various treatments, treatment $\mathrm{T}_{11}$ receiving 75 per cent $\mathrm{RDF}+\mathrm{FYM}$ and $\mathrm{VC}(1: 1)$ equivalent to 25 per cent RDN registered better growth and yield parameters such as, maximum plant height $(35.36 \mathrm{~cm})$, number of leaves $(21.10)$, plant spread $(69.64 \mathrm{~cm})$, stalk length $(9.85 \mathrm{~cm})$, diameter of head $(13.76 \mathrm{~cm})$ at harvest, minimum days taken for head initiation (35.92 days), average head weight (845 g) and head yield (37.18 $\left.\mathrm{t} \mathrm{ha}^{-1}\right)$

\section{Introduction}

Red cabbage is a nutritious and delicious vegetable. It is an excellent source of calcium, manganese, magnesium, iron, potassium, vitamin $\mathrm{C}, \mathrm{A}, \mathrm{E}, \mathrm{K}$ and dietary fibre. Red cabbage being a heavy feeder and exhaustive crop responds very well to nutrients application. The increasing use of chemical fertilizers to increase vegetable production has been widely recognized but its long run impact on soil health, ecology and other natural resources are detrimental which affect living organisms including beneficial soil microorganisms and human being. The escalating prices of chemical fertilizers and its detrimental impact on the soil health, environment and human health urged the farmer to adopt alternative source of nutrients for vegetable production. Therefore, to reduce 
dependency on chemical fertilizers and conserving the natural resources in align with sustainable vegetable production are vital issues in present time which is only possible through integrated plant nutrient supply system (Merentola et al., 2012). Besides fertilizers, there are several sources of plant nutrients like organic manures, biofertilizers etc. These nutrient sources apart from manuring of soil also improve overall soil productivity (Chumyani et al., 2012). Therefore, the study was undertaken to find out the study influence of INM on growth and yield of red cabbage grown under shade house.

\section{Materials and Methods}

The experiment was carried out in Hi-Tech Horticulture Unit, Main Agricultural Research Station, Saidapur farm, University of Agricultural Sciences Dharwad. The experiment consists of fourteen treatments and two replications laid out in a randomized complete block design. The treatments consists of $\mathrm{T}_{1}-100 \% \mathrm{RDF}+\mathrm{FYM} @ 25 \mathrm{tha}^{-1}$ (Control), $\mathrm{T}_{2-}-75 \% \mathrm{RDF}+\mathrm{FYM}$ equivalent to $25 \% \mathrm{RDN}, \mathrm{T}_{3}-75 \% \mathrm{RDF}+\mathrm{FYM}$ equivalent to $25 \% \mathrm{RDN}+$ Azatobactor $+\mathrm{PSB}, \mathrm{T}_{4}-75 \%$ $\mathrm{RDF}+\mathrm{VC}$ equivalent to $25 \% \mathrm{RDN}, \mathrm{T}_{5^{-}} 75 \%$ $\mathrm{RDF}+\mathrm{VC}$ equivalent to $25 \% \mathrm{RDN}+$ Azatobactor $+\mathrm{PSB}, \mathrm{T}_{6}-50 \% \mathrm{RDF}+\mathrm{FYM}$ equivalent to $50 \% \mathrm{RDN}, \mathrm{T}_{7-} 50 \% \mathrm{RDF}+$ FYM equivalent to $50 \% \mathrm{RDN}+$ Azatobactor $+\mathrm{PSB}, \mathrm{T}_{8}-50 \% \mathrm{RDF}+\mathrm{VC}$ equivalent to 50 $\% \mathrm{RDN}, \mathrm{T}_{9}-50 \% \mathrm{RDF}+\mathrm{VC}$ equivalent to 50 $\% \mathrm{RDN}+$ Azatobactor $+\mathrm{PSB}, \mathrm{T}_{10^{-}} 75 \% \mathrm{RDF}$ + Each FYM \& VC (1:1) equivalent to $25 \%$ RDN, $\mathrm{T}_{11}-75 \% \mathrm{RDF}+$ Each FYM \& VC (1:1) equivalent to $25 \% \mathrm{RDN}+$ Azatobactor $+\mathrm{PSB}, \mathrm{T}_{12}-50 \% \mathrm{RDF}+$ Each FYM \& VC (1:1) equivalent to $50 \% \mathrm{RDN}, \mathrm{T}_{13}-50 \% \mathrm{RDF}$ + Each FYM \& VC $(1: 1)$ equivalent to $50 \%$ $\mathrm{RDN}+$ Azotobacter $+\mathrm{PSB}$ and $\mathrm{T}_{14^{-}}$Each FYM \& VC (1:1) equivalent to $100 \% \mathrm{RDN}+$ Azatobactor + PSB (Organic).
Note: $\mathrm{FYM}=$ Farm yard manure, $\mathrm{VC}=$ Vermicompost, Recommended dose of fertilizer $($ RDF $)$ for cabbage $=150: 100: 125 \mathrm{~kg}$ NPK $\mathrm{ha}^{-1}+$ FYM, PSB=Phosphate solubilizing bacterium.

The experiment was carried out in a shade house covered using 35 per cent green colour shading net. Seedlings of red cabbage variety Red queen were raised by sowing the seeds in plastic portrays (98 cells) by using coco peat as growing media. The protrays were filled with the coco peat as growing media. Seeds were sown and were covered with a thin layer of same growing medium, watered lightly. 45 days old seedlings were transplanted on the raised beds at spacing of $45 \times 30 \mathrm{~cm}$ distance inside the shade house. Recommended dose of FYM (25 t/ha) applied to all the treatments commonly. The entire calculated dose of Vermicompost and farmyard manure as per treatment combinations were applied in the individual specified plots two weeks before transplanting of the seedlings by broadcasting method and was thoroughly mixed up well with the soil. Before transplanting of the seedlings recommended dose of NPK were applied as per treatment combination. The observations were recorded for growth and yield parameters like, plant height, number of leaves, plant spread, stalk length, diameter of head at harvest, minimum days taken for head initiation, average head weight and head yield. The data on various observations collected during period of study were subjected to statistical analysis as described by Gomez and Gomez (1984).

\section{Results and Discussion}

The data pertaining to the various observations on growth and yield parameters in red cabbage have been shown in Table 1, 2 and 3 . Application of 75 per cent RDF + FYM and VC (1:1) equivalent to 25 per cent RDN (recommended dose of nitrogen) + 
Azotobactor + PSB (Phosphate solubalizing bacteria) $-T_{11}$ recorded significantly higher plant height $(35.36 \mathrm{~cm})$ at harvest which was on par with $\mathrm{T}_{10}, \mathrm{~T}_{13}$ and $\mathrm{T}_{9}$ and lowest plant height was recorded in control $(30.22 \mathrm{~cm})$ receiving 100 per cent RDF + FYM $\left(T_{1}\right)$. This increased plant height might be due to the favorable effect of chemical fertilizers along with vermicompost and FYM which might have enhanced the soil fertility coupled with improved soil moisture retention capacity (Chaudhary et al., 2015).). Earlier workers attributed this to application of biofertilizers helped in secretion of growth promoting substances, which might have lead to better root development, transportation of water, uptake and deposition of nutrients (Tekasangla et al., 2015). Present findings are in agreement with those reported by Maurya et al., (2008) in broccoli and Singh et al., (2009) in cauliflower

The number of leaves in red cabbage was significantly influenced by application of different source of nutrients. The maximum number of leaves at harvest were recorded in $\mathrm{T}_{11}$ (21.10) receiving 75 per cent RDF + FYM and VC (1:1) equivalent to 25 per cent RDN + Azotobactor + PSB which was on par with $\mathrm{T}_{9}$ and $\mathrm{T}_{13}$ and minimum number of leaves were recorded in control (15.30).

This increase in number of leaves might be due to increased absorption of primary nutrients which resulted in increased synthesis of carbohydrates, proteins and fats which are utilized in building up of new cells. These results are in conformity with findings of Chaudhary et al., (2015) while in working with cabbage and Maurya et al., (2008) in broccoli.

Significantly higher plant spread at harvest was recorded in $T_{11}(69.64 \mathrm{~cm})$ receiving 75 per cent RDF + FYM and VC (1:1) equivalent to 25 per cent RDN + Azotobactor + PSB which was on par with $T_{9}, T_{5}$ and $T_{13}$ and lower plant spread was recorded in control $(55.35 \mathrm{~cm})$. This increased plant spread might be due to added vermicompost and FYM in integrated nutrient management (INM) which might have improved the physical, chemical and biological properties of soil which in turn helps in better nutrient absorption and utilization by plant resulting in better plant growth. This might be attributed to certain growth promoting substances secreted by the biofertilizers which in turn helps in better root development, better transportation of water, uptake and deposition of nutrients (Tekasangla et al., 2015). In red cabbage significantly higher stalk length was recorded in $\mathrm{T}_{11}(9.85$ $\mathrm{cm})$ receiving 75 per cent $\mathrm{RDF}+\mathrm{FYM}$ and VC (1:1) equivalent to 25 per cent RDN + Azotobactor + PSB which was on par with $\mathrm{T}_{13}$ and $T_{9}$ and lower stalk length was recorded in control $(7.60 \mathrm{~cm})$. This might be due increased uptake and continuous supply of primary nutrients which might have enhanced cell division and cell elongation. Earlier researchers attributed this to integrated use of nutrients which has enhanced cell division, multiplication and cell elongation in meristematic region of plant ultimately promoting the vegetative growth of the plant (Kumar et al., 2013b). Results of the present study are in line with findings of Kachari and Korla (2009) and Singh et al., (2009) in cauliflower.

Head diameter of red cabbage differed significantly with application of different source of nutrients.

The treatment $\left(T_{11}\right)$ receiving combination of inorganic fertilizers (75\% RDF), organics (FYM and VC (1:1) equivalent to 25 per cent RDN and biofertilizers (Azotobactor + PSB) recorded higher head diameter $(13.76 \mathrm{~cm})$ which was on par with $\mathrm{T}_{13}$ and $\mathrm{T}_{9}$ and lower head diameter was recorded in control (11 $\mathrm{cm})$. 
Table.1plant height $(\mathrm{cm})$, number of leaves and plant spread $(\mathrm{cm})$ as influenced by integrated nutrient management in red cabbage grown under shade house

\begin{tabular}{|c|c|c|c|}
\hline Treatment & $\begin{array}{l}\text { Plant height at } \\
\text { harvest }(\mathbf{c m})\end{array}$ & $\begin{array}{c}\text { Number of leaves at } \\
\text { harvest }\end{array}$ & $\begin{array}{l}\text { Plant spread at } \\
\text { harvesting }(\mathrm{cm})\end{array}$ \\
\hline$T_{1}-100 \%$ RDF + FYM (Control) & 30.22 & 15.30 & 55.35 \\
\hline $\mathrm{T}_{2}-75 \% \mathrm{RDF}+\mathrm{FYM}$ equivalent to $25 \% \mathrm{RDN}$ & 31.89 & 16.20 & 56.88 \\
\hline $\mathrm{T}_{3}-75 \% \mathrm{RDF}+\mathrm{FYM}$ equivalent to $25 \% \mathrm{RDN}+$ Azatobactor + PSB & 32.63 & 17.69 & 61.80 \\
\hline $\mathrm{T}_{4}-75 \% \mathrm{RDF}+\mathrm{VC}$ equivalent to $25 \% \mathrm{RDN}$ & 33.26 & 17.26 & 59.50 \\
\hline $\mathrm{T}_{5}-75 \% \mathrm{RDF}+\mathrm{VC}$ equivalent to $25 \% \mathrm{RDN}+$ Azatobactor + PSB & 33.30 & 18.08 & 68.52 \\
\hline $\mathrm{T}_{6}-50 \% \mathrm{RDF}+\mathrm{FYM}$ equivalent to $50 \% \mathrm{RDN}$ & 33.21 & 17.04 & 64.90 \\
\hline $\mathrm{T}_{7}-50 \% \mathrm{RDF}+\mathrm{FYM}$ equivalent to $50 \% \mathrm{RDN}+$ Azatobactor + PSB & 32.10 & 18.30 & 61.51 \\
\hline $\mathrm{T}_{8}-50 \% \mathrm{RDF}+\mathrm{VC}$ equivalent to $50 \% \mathrm{RDN}$ & 32.93 & 16.54 & 61.60 \\
\hline $\mathrm{T}_{9}-50 \% \mathrm{RDF}+\mathrm{VC}$ equivalent to $50 \% \mathrm{RDN}+$ Azatobactor + PSB & 33.83 & 20.43 & 68.70 \\
\hline $\mathrm{T}_{10}-75 \% \mathrm{RDF}+\mathrm{FYM}$ and VC (1:1) equivalent to $25 \% \mathrm{RDN}$ & 34.10 & 16.31 & 65.70 \\
\hline $\mathrm{T}_{11}-75 \% \mathrm{RDF}+\mathrm{FYM}$ and VC (1:1) equivalent to $25 \% \mathrm{RDN}+$ Azatobactor + PSB & 35.36 & 21.10 & 69.64 \\
\hline$T_{12}-50 \%$ RDF + FYM and VC (1:1) equivalent to $50 \%$ RDN & 32.74 & 17.41 & 64.53 \\
\hline $\mathrm{T}_{13}-50 \% \mathrm{RDF}+\mathrm{FYM}$ and VC (1:1) equivalent to $50 \% \mathrm{RDN}+$ Azatobactor + PSB & 33.93 & 20.40 & 68.25 \\
\hline $\mathrm{T}_{14}$ - Each FYM and VC (1:1) equivalent to $100 \% \mathrm{RDN}+$ Azatobactor + PSB & 31.69 & 17.35 & 64.07 \\
\hline S.Em. \pm & 0.54 & 0.26 & 0.47 \\
\hline C.D. at $5 \%$ & 1.72 & 0.81 & 1.45 \\
\hline
\end{tabular}


Table.2 Stalk length $(\mathrm{cm})$, days taken for head initiation (days) and head diameter $(\mathrm{cm})$ as influenced by integrated nutrient management in red cabbage grown under shade house

\begin{tabular}{|c|c|c|c|}
\hline Treatment & $\begin{array}{l}\text { Stalk length } \\
\quad(\mathrm{cm})\end{array}$ & $\begin{array}{l}\text { Days taken for } \\
\text { head initiation } \\
\text { (days) }\end{array}$ & $\begin{array}{l}\text { Head diameter } \\
(\mathrm{cm})\end{array}$ \\
\hline$T_{1}-100 \%$ RDF + FYM (Control) & 7.60 & 39.10 & 11.00 \\
\hline $\mathrm{T}_{2}-75 \% \mathrm{RDF}+\mathrm{FYM}$ equivalent to $25 \% \mathrm{RDN}$ & 8.05 & 38.54 & 12.62 \\
\hline $\mathrm{T}_{3}-75 \% \mathrm{RDF}+\mathrm{FYM}$ equivalent to $25 \% \mathrm{RDN}+$ Azatobactor + PSB & 8.65 & 39.80 & 12.50 \\
\hline $\mathrm{T}_{4}-75 \% \mathrm{RDF}+\mathrm{VC}$ equivalent to $25 \% \mathrm{RDN}$ & 8.50 & 39.83 & 11.74 \\
\hline $\mathrm{T}_{5}-75 \% \mathrm{RDF}+\mathrm{VC}$ equivalent to $25 \% \mathrm{RDN}+$ Azatobactor + PSB & 8.80 & 39.10 & 12.69 \\
\hline $\mathrm{T}_{6}-50 \% \mathrm{RDF}+\mathrm{FYM}$ equivalent to $50 \% \mathrm{RDN}$ & 8.85 & 39.90 & 12.56 \\
\hline $\mathrm{T}_{7}-50 \% \mathrm{RDF}+\mathrm{FYM}$ equivalent to $50 \% \mathrm{RDN}+$ Azatobactor + PSB & 8.70 & 37.96 & 12.52 \\
\hline $\mathrm{T}_{8}-50 \% \mathrm{RDF}+\mathrm{VC}$ equivalent to $50 \% \mathrm{RDN}$ & 8.29 & 38.83 & 11.73 \\
\hline $\mathrm{T}_{9}-50 \% \mathrm{RDF}+\mathrm{VC}$ equivalent to $50 \% \mathrm{RDN}+$ Azatobactor $+\mathrm{PSB}$ & 9.30 & 36.16 & 13.03 \\
\hline $\mathrm{T}_{10}-75 \%$ RDF + FYM and VC (1:1) equivalent to $25 \%$ RDN & 8.30 & 39.15 & 12.36 \\
\hline $\mathrm{T}_{11}-75 \% \mathrm{RDF}+\mathrm{FYM}$ and VC (1:1) equivalent to $25 \% \mathrm{RDN}+$ Azatobactor + PSB & 9.85 & 35.92 & 13.76 \\
\hline$T_{12}-50 \%$ RDF + FYM and VC (1:1) equivalent to $50 \%$ RDN & 8.60 & 38.60 & 12.65 \\
\hline $\mathrm{T}_{13}-50 \% \mathrm{RDF}+\mathrm{FYM}$ and VC (1:1) equivalent to $50 \% \mathrm{RDN}+$ Azatobactor + PSB & 9.55 & 37.06 & 13.40 \\
\hline $\mathrm{T}_{14}$ - Each FYM and VC (1:1) equivalent to $100 \% \mathrm{RDN}+$ Azatobactor + PSB & 7.90 & 40.55 & 11.62 \\
\hline S.Em. \pm & 0.21 & 0.83 & 0.38 \\
\hline C.D. at $5 \%$ & 0.65 & 2.53 & 1.16 \\
\hline
\end{tabular}


Table.3 Average head weight $(\mathrm{g})$ and head yield $\mathrm{ha}^{-1}(\mathrm{t})$ as influenced by integrated nutrient management in red cabbage grown under shade house condition

\begin{tabular}{|c|c|c|}
\hline Treatment & $\begin{array}{c}\text { Average head } \\
\text { weight (g) }\end{array}$ & $\begin{array}{l}\text { Head yield } \\
\text { (t/ha) }\end{array}$ \\
\hline $\mathrm{T}_{1}-100 \% \mathrm{RDF}+\mathrm{FYM}$ (Control) & 550.00 & 24.20 \\
\hline $\mathrm{T}_{2}-75 \% \mathrm{RDF}+\mathrm{FYM}$ equivalent to $25 \% \mathrm{RDN}$ & 620.00 & 27.28 \\
\hline $\mathrm{T}_{3}-75 \%$ RDF + FYM equivalent to $25 \%$ RDN + Azatobactor + PSB & 615.00 & 28.03 \\
\hline $\mathrm{T}_{4}-75 \% \mathrm{RDF}+\mathrm{VC}$ equivalent to $25 \% \mathrm{RDN}$ & 620.00 & 27.28 \\
\hline $\mathrm{T}_{5}-75 \% \mathrm{RDF}+\mathrm{VC}$ equivalent to $25 \% \mathrm{RDN}+$ Azatobactor + PSB & 730.00 & 32.12 \\
\hline $\mathrm{T}_{6}-50 \% \mathrm{RDF}+\mathrm{FYM}$ equivalent to $50 \% \mathrm{RDN}$ & 606.00 & 26.66 \\
\hline $\mathrm{T}_{7}-50 \% \mathrm{RDF}+\mathrm{FYM}$ equivalent to $50 \% \mathrm{RDN}+$ Azatobactor + PSB & 723.00 & 31.81 \\
\hline $\mathrm{T}_{8}-50 \% \mathrm{RDF}+\mathrm{VC}$ equivalent to $50 \% \mathrm{RDN}$ & 660.00 & 29.01 \\
\hline $\mathrm{T}_{9}-50 \% \mathrm{RDF}+\mathrm{VC}$ equivalent to $50 \% \mathrm{RDN}+$ Azatobactor + PSB & 791.00 & 34.80 \\
\hline $\mathrm{T}_{10}-75 \% \mathrm{RDF}+\mathrm{FYM}$ and VC (1:1) equivalent to $25 \% \mathrm{RDN}$ & 650.00 & 28.60 \\
\hline $\mathrm{T}_{11}-75 \% \mathrm{RDF}+\mathrm{FYM}$ and VC (1:1) equivalent to $25 \% \mathrm{RDN}+$ Azatobactor + PSB & 845.00 & 37.18 \\
\hline $\mathrm{T}_{12}-50 \% \mathrm{RDF}+\mathrm{FYM}$ and VC (1:1) equivalent to $50 \% \mathrm{RDN}$ & 630.00 & 27.72 \\
\hline $\mathrm{T}_{13}-50 \% \mathrm{RDF}+\mathrm{FYM}$ and VC (1:1) equivalent to $50 \% \mathrm{RDN}+$ Azatobactor + PSB & 789.00 & 33.80 \\
\hline T $_{14}$ - Each FYM and VC (1:1) equivalent to $100 \%$ RDN + Azatobactor + PSB & 637.00 & 26.06 \\
\hline S.Em. \pm & 19.09 & 0.84 \\
\hline C.D. at $5 \%$ & 57.81 & 2.57 \\
\hline
\end{tabular}


This might be due to synergestic effect of vermicompost, FYM and biofertilizers provided better nourishment to plants due to sustained release of nutrients and increased growth parameters ultimately increased head diameter (Chaudhary et al., 2015) Days taken for head initiation were significantly influenced by application of different source of nutrients. Earliest head initiation was recorded in $\mathrm{T}_{11}$ (35.92days) receiving 75 per cent RDF + FYM and VC (1:1) equivalent to 25 per cent RDN + Azotobactor + PSB which was on par with $\mathrm{T}_{9}, \mathrm{~T}_{7}$ and $\mathrm{T}_{13}$. While head initiation was delayed by about 5 days in $\mathrm{T}_{14}$ receiving only organic manures and biofertilizers compared to $T_{11}$. The minimum days taken for head initiation may be due to higher NPK and increased nutrient transport from root to the aerial parts and increased rate of photosynthesis and assimilation of photosynthates resulting in early head formation (Kumari et al., 2015). These results are in line with findings of Sangeetashree et al., (2014) in cauliflower.

Average head weight differed significantly due to combined application of different source of nutrients. Maximum head weight of $845 \mathrm{~g}$ was recorded with combined application of 75 per cent RDF + FYM and VC (1:1) equivalent to 25 per cent RDN + Azotobactor + PSB which was on par with $T_{9}$ and $T_{13}$. Whereas, least average head weight was recorded in control $(550 \mathrm{~g})$. Increase in head weight of red cabbage might be due to the fact that biofertilizers in combination with inorganic and organic fertilizers helped in better root proliferation and rhizosphere development, uptake of nutrients and water, higher leaf area development ultimately higher rate of photosynthetic activity (Chaudhary et al., 2015). These findings are in agreement with those reported by Bahadur et al., 2006 in cabbage, Maurya et al., 2008 in broccoli.

Yield per hectare were significantly influenced by combined application of different source of nutrients. Treatment $\mathrm{T}_{11}$ receiving 75 per cent RDF + FYM and VC (1:1) equivalent to 25 per cent $\mathrm{RDN}+$ Azotobactor + PSB recorded higher yield of $37.18 \mathrm{t} \mathrm{ha}^{-1}$ which was on par with $\mathrm{T}_{9}(34.80 \mathrm{t}$ $\mathrm{ha}^{-1}$ ) receiving 50 per cent $\mathrm{RDF}+\mathrm{VC}$ equivalent to 50 per cent RDN + Azotobactor + PSB and $T_{13}\left(33.80 \mathrm{t} \mathrm{ha}^{-1}\right)$ receiving 50 per cent RDF + FYM and VC (1:1) equivalent to 50 per cent RDN + Azotobactor + PSB and lower yield $\left(24.20 \mathrm{t} \mathrm{ha}^{-1}\right)$ was recorded in treatment receiving 100 per cent $\mathrm{RDF}$ and FYM (control). The more yield in this treatment could be directly related to higher values of head diameter, head weight and photosynthetic rate. The increased in yield might be due to the performance of the vegetative growth which might have influenced the production of more amounts of carbohydrates accumulated in head and thereby increased the yield. This may be because of appropriate dose of nitrogen, as nitrogen is a constituent of protein and chlorophyll and it play vital role in photosynthesis process. Further, application of NPK in conjunction with biofertilizers might have favored the effective utilization of nutrient availability in the soil, which in turn increased the yield per hectare. These results are in consonance with those reported by Chaudhary et al., 2015, Tekasangla et al., 2015 in cauliflower, Merentola et al., 2012 in cabbage

\section{Acknowledgement}

I place my gratitude and sincere thanks to my chairman Dr. S. M. Mantur, Professor and Head, High-Tech Horticulture unit, UAS, Dharwad for his meticulous and infallible guidance with sustained interest, enthusiastic encouragement, kind treatment and critical appraisal throughout the period of this investigation. I acknowledge my heartfelt thanks to members of my advisory committee Dr. M. S. Biradar, 
Assistant Professor, Department of Horticulture, University of Agricultural Sciences, Dharwad, Dr. Shripad kulkarni, Professor of Plant Pathology, University of Agricultural Sciences, Dharwad, for their infallible guidance, valuable suggestions, untiring help and constant encouragement.

\section{References}

Bahadur, A., Singh, J., Singh, K. P., Upadhyay, A. K. and Rai, M., 2006, Effect of organic amendments and biofertilizers on growth, yield and quality attributes of chinese cabbage (Brassica pekinensis). Indian J. Agric. Sci., 76 (10) : 596-598.

Chaudhary, M. M., Bhanvadia, A. S. and Parmar P. N., 2015, Effect of integrated nutrient management on growth, yield attributes and yield of cabbage (Brassica oleracea $\mathrm{L}$. var. capitata). Trends in Biosciences, 8 (8) :2164-2168.

Chumyani, Kanaujia, S. P., Singh, A. K. and Singh, V. B., 2012, Effect of integrated nutrient management on growth, yield and quality of tomato (Lycopersicon esculentum). J. Soil Crops, 22: 5-9.

Gomez, A. A. and Gomez. K. A., 1984, Statistical Procedures for Agricultural Research. $2^{\text {nd }}$ Ed. A Wiley Inheritance Publication, New York, pp. 187-241.

Kachari, M. and Korla, B. N., 2009, Effect of biofertilizers on growth and yield of cauliflower cv. PSB K- 1. Indian J. Hort., 66 (4) : 496-501.

Kumar, S., Singh, J. P., Rajbeer, NathiRam, BrajMohan, Kaushik, H. and Kumar, D., 2013b, Influence of integrated nutrient management on growth and yield of cauliflower (Brassica oleracea L. var. botrytis) cv.NHB-1012. Int J. Agric Sci., 9 (2) : 747-749.

Kumari, C., Mankar, A., Karuna, K., Solankey, S. S. and Singh, V. K., 2015, Effect of different levels of nitrogen and microbial inoculants on yield and quality of cabbage (Brassica oleracea L. var. capitata) cv Pride of India. Indian J. Agric. Sci., 85 (4) :515-518.

Maurya, A. K., Singh, M. P., Srivastava, B. K., Singh, Y. V., Singh, D. K., Singh, S. and Singh, P. K., 2008, Effect of organic manures and inorganic fertilizers on growth characters, yield and economics of sprouting broccoli cv. Fiesta. Indian $J$. Hort., 65 (1) : 116- 118.

Merentola, Kanaujia. S. P. and Singh, V. B., 2012, Effect of integrated nutrient management on growth, yield and quality of cabbage (Brassica oleraceae L. var. capitata). J. Soils and Crops, 22 (2) : 233239.

Sangeetashree, S., Singh, V. K. and Ravikumar. 2014, Effect of integrated nutrient management on yield and quality of cauliflower (Brassica oleracea L. var. botrytis). International quarterly journal of life science. 9 (3) : 1053-1058.

Singh, A., Singh, T. and Singh, B. N., 2009, Influence of integrated nutrient management growth, yield and economics of cauliflower (Brassica oleracea L. var. botrytis). Veg. Sci., 36 (3) : 340-343.

Tekasangla, Kanaujia, S. P. and Singh, P. K., 2015, Integrated nutrient management for quality production of cauliflower in acid alfisol of Nagaland. Karnataka J. Agric. Sci.,28 (2): 244-247.

\section{How to cite this article:}

Shruti Koppad, S. M. Mantur, M. S. Biradar and Shripad Kulkarni 2019. Effect of Integrated Nutrient Management in Red Cabbage Grown under Shade House Condition. Int.J.Curr.Microbiol.App.Sci. 8(09): 1294-1301. doi: https://doi.org/10.20546/ijcmas.2019.809.148 